\title{
- Mutagenic evaluation of the pesticides captan, folpet, captafol, dichlofluanid and related compounds with the mutants TA102 and TA104 of Salmonella typhimurium
}

\section{Carmen Barrueco and Eduardo de la Peña}

Instituto de Edafología y Biología Vegetal (CSIC), Serrano 115, dpdo 28006 Madrid, Spain

A mutagenic evaluation of captan, folpet, captafol, dichlofluanid and related compounds was carried out using the Salmonella/mammalian microsome test using strains TA102 and TA104. These strains contain A-T base pairs at the site of the mutation in contrast to the other Salmonella tester strains that detect mutagens damaging G-C base pairs. In addition, the excision repair system of the TA102 strain is still intact. Captan and folpet were mutagenic in strain TA104, captafol was mutagenic in strain TA102, whereas the remaining test compounds (dichlofluanid, tetrahydrophthalimide and thiozolidine-4-carboxylic acid) were not mutagenic in either strain. In conclusion, we consider it of value to add these two strains to those already used in the Ames test in order to increase confidence in our ability to detect mutagens and to shed further light on their mechanism of action.

\section{Introduction}

Many authors have evaluated the mutagenicity of captan and other related pesticides (folpet, captafol and dichlofluanid) using the Salmonella/mammalian microsome or Ames test. In most cases, the tests were carried out with the strains initially described by Ames, i.e. his G-46, TA1535, TA1530, TA1950, TA1536, TA1537, TA1538 (Ames et al., 1973), TA98 and TA100 (Ames et al., 1975). Captan and folpet were mutagenic in those strains which detect base-pair substitution mutations and in those that detect frameshift mutations (Bridges, 1975; McCann and Ames, 1975; Ficsor et al., 1977; Carere et al., 1978; de Flora, 1978; Moriya et al., 1978; Hollstein and McCann, 1979; Rinkus and Legator, 1979; de Flora and Boido, 1980; Shiau et al., 1981; Waters et al., 1982; IARC, 1983; de Flora et al., 1984; Xu et al., 1984). With captafol and dichlofluanid, the most sensitive strain was TA100 although the weak mutagenic effect caused by these products was not always observed (Shirasu et al., 1977; Kawachi et al., 1980; Schuphan et al., 1981; Moriya et al., 1983; Schuphan and Casida, 1983).

At present, the strains recommended by Maron and Ames (1983) for general mutagenicity tests are TA100, TA98, TA97 and TA102. However, there is no published information on the mutagenicity of these products using TA102 strain. In this study we provide information on the mutagenicity of captan and folpet in TA102 and TA104 strains. In contrast to the other Salmonella tester strains which detect mutagens damaging G-C base pairs, these strains contain A-T base pairs at the site of the mutation and TA102 is excision repair proficient.

\section{Materials and methods}

\section{Chemicals}

Captan, folpet, captafol and dichlofluanid were supplied by the US Environmental Protection Agency (EPA).

Tetrahydrophthalimide (a captan metabolite) and thiazolidine-4-carboxylic acid (related to a captan metabolite) were supplied by Fluka and Aldrich respectively.

Table I gives names, chemical structure, mol. wt, purity and source of chemicals evaluated. These compounds were dissolved in dimethyl sulphoxide (DMSO) supplied by Merck.

Methylglioxal, methyl methane sulphonate and 2-aminoanthracene (standard mutagens) were supplied by Aldrich, Merck and Sigma respectively.

The concentration range for each tested compound was selected according to preliminary study results.

Bacterial strains

Salmonella typhimurium strains TA102 and TA104 were obtained from Dr B.N. Ames, University of California at Berkeley. Their genotype has been described previously (Levin et al., 1982; Maron and Ames, 1983).

Metabolic activation system

The supernatant of the post-mitochondrial liver fraction (S9) from Wistar rats $(250-500 \mathrm{~g}$ body $w \mathrm{t})$ was used as metabolic activation system. A week before $(250-500 \mathrm{~g}$ body $\mathrm{wt}$ ) was used as metabolic activation system. A week before Immediately before the mutagenicity tests, $\mathbf{S 9}$ mix was prepared, i.e. $\mathrm{S} 9$ with NADP and glucose-6-phosphate cofactors.

S9 and S9 mix fractions were prepared according to the method described by Maron and Ames (1983).

Salmonella/mammalian-microsome test

The standard plate incorporation test was used (Ames et al., 1975; Maron and Ames, 1983).

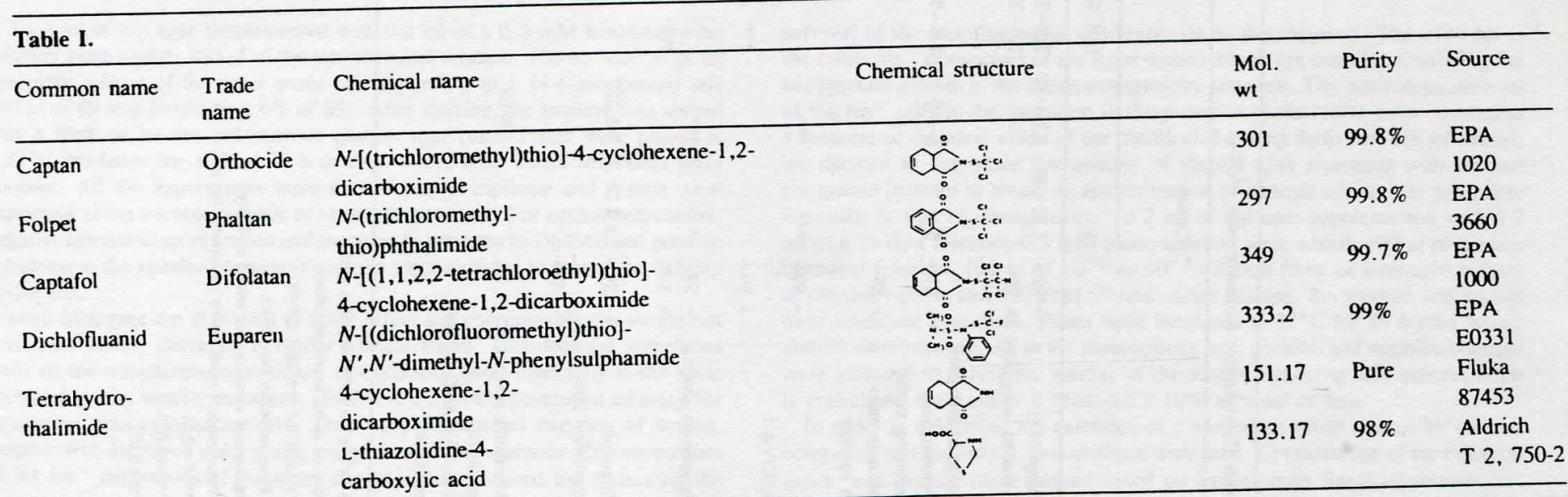

(c) IRL Press Limited. Oxford, England 


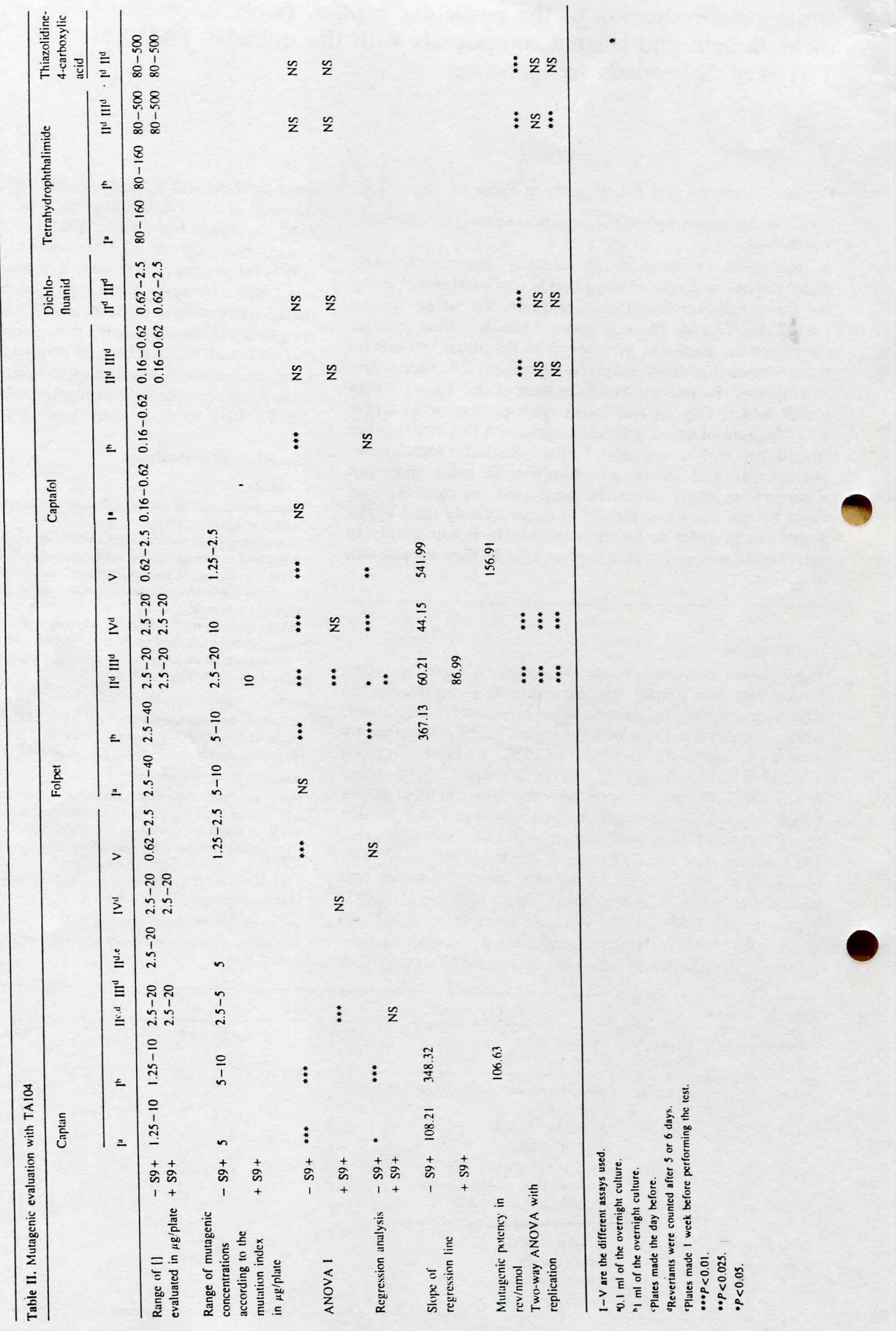


Table III. Mutagenic evaluation of captan with TA104

(a) Without $\mathrm{S} 9 \mathrm{mix}$

Assay I

\begin{tabular}{|c|c|c|c|c|c|c|c|c|c|}
\hline $\begin{array}{l}\text { Captan } \\
\text { ( } \mu \mathrm{g} / \text { plate) }\end{array}$ & $\mathrm{R}$ & MI & Q & V & $\begin{array}{l}\text { Captan } \\
(\mu \mathrm{g} / \text { plate })\end{array}$ & $\mathrm{R}$ & MI & Q & V \\
\hline 1.25 & $178 \pm 101.82$ & 0 & NM & $4 \times 10^{8}$ & 2.5 & $1432 \pm 452.55$ & 4.8 & $\mathrm{M}^{2+}$ & $3 \times 10^{8}$ \\
\hline 2.5 & $327 \pm 18.38$ & 0.3 & NM & $4 \times 10^{8}$ & 5 & 1904 & 6.7 & $\mathrm{M}^{3+}$ & $10^{8}$ \\
\hline 5 & $668 \pm 96.17$ & 2.5 & $\mathrm{M}^{+}$ & $4 \times 10^{8}$ & 10 & 1692 & 5.9 & $\mathrm{M}^{3+} / \mathrm{T}$ & $<10^{7}$ \\
\hline 10 & $199 \pm 72.12$ & 0 & $\mathrm{NM} / \mathrm{T}$ & $2 \times 10^{7}$ & 20 & 352 & 0.3 & $\mathrm{NM} / \mathrm{T}$ & $2 \times 10^{6}$ \\
\hline SM & $153 \pm 66.47$ & & & $6 \times 10^{8}$ & SM & 238 & & & $3 \times 10^{8}$ \\
\hline DMSO & $278 \pm 43.84$ & 1.8 & NM & $6 \times 10^{8}$ & DMSO & 286 & 1.2 & NM & $3 \times 10^{8}$ \\
\hline MG & 5000 & 30.8 & $\mathrm{M}^{4+}$ & $5 \times 10^{8}$ & MG & 4500 & 17.7 & $\mathrm{M}^{4+}$ & $2 \times 10^{8}$ \\
\hline \multicolumn{5}{|l|}{ Assay IV ${ }^{\mathbf{a}}$} & \multicolumn{5}{|l|}{ Assay V } \\
\hline $\begin{array}{l}\text { Captan } \\
\text { ( } \mu \mathrm{g} / \text { plate) }\end{array}$ & $\mathrm{R}$ & MI & Q & V & $\begin{array}{l}\text { Captan } \\
(\mu \mathrm{g} / \text { plate })\end{array}$ & $\mathrm{R}$ & MI & $\mathrm{Q}$ & V \\
\hline 2.5 & $139 \pm 12.90$ & 0.3 & NM & $10^{7}$ & 0.62 & $675 \pm 108.19$ & 1.2 & NM & $2 \times 10^{9}$ \\
\hline 5 & $435 \pm 23.35$ & 2.3 & NM & $10^{7}$ & 1.25 & $2132 \pm 62.22$ & 5.9 & $\mathrm{M}^{3+}$ & $2 \times 10^{9}$ \\
\hline 10 & $268 \pm 93.21$ & 1.2 & $\mathrm{NM} / \mathrm{T}$ & $<10^{7}$ & 2.5 & $2560 \pm 90.51$ & 7.3 & $\mathrm{M}^{3+}$ & $2 \times 10^{9}$ \\
\hline 20 & $46 \pm 6.43(s)$ & & $\mathrm{T}$ & $2 \times 10^{6}$ & & & & & \\
\hline SM & $150 \pm 13.50$ & & & $10^{7}$ & SM & $306 \pm$ & & & $2 \times 10^{9}$ \\
\hline DMSO & $90 \pm 37.29$ & 0.6 & NM & $10^{7}$ & DMSO & $312 \pm$ & 1 & NM & $2 \times 10^{9}$ \\
\hline MG & 2300 & 14.7 & $\mathrm{M}^{4+}$ & $10^{7}$ & MG & 4250 & 12.8 & $\mathrm{M}^{4+}$ & $2 \times 10^{9}$ \\
\hline
\end{tabular}

(b) With $\mathrm{S} 9 \mathrm{mix}$

Assay III $^{\mathrm{a}}$

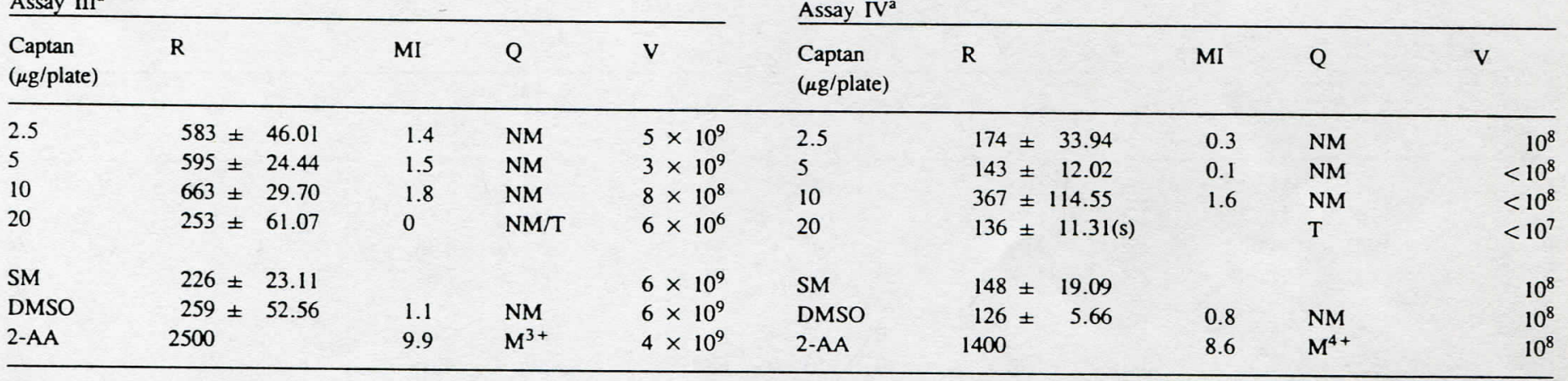

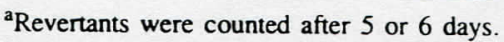

$\mathrm{R}$, revertants expressed as the $\bar{x} \pm \mathrm{SD}$; MI, mutation index; $\mathrm{Q}$, quality; V, number of viables/ml; s, small colonies; SM, spontaneous mutation; DMSO, mutation in response to DMSO; MG mutation in response to methylglioxal; 2-AA, mutation in response to 2-aminoanthracene.

$\mathrm{NM}$, non-mutagenic $(\mathrm{MI}<2.5)$;

$\mathrm{M}^{+}$, very weak mutagenic $(\mathrm{MI}=2.5-3.5)$

$\mathrm{M}^{2+}$, weak mutagenic $(\mathrm{MI}=3.6-5.5)$;

$\mathrm{M}^{3+}$, mutagenic $(\mathrm{MI}=5.6-10.5)$;

$\mathrm{M}^{4+}$, highly mutagenic $(\mathrm{MI}>10.5)$;

$T$, toxic effect.

To $2 \mathrm{ml}$ of top agar supplemented with $0.2 \mathrm{ml}$ of a $0.5 \mathrm{mM}$ histidine/biotin solution were added: $100 \mu \mathrm{l}$ of the test chemical solution, 100 or $1000 \mu \mathrm{l}$ of an overnight culture of the tester strain (corresponding to a 14-h incubation) and $500 \mu \mathrm{l}$ of S $9 \mathrm{mix}$ (containing $4 \%$ of S9). After shaking, the mixture was spread onto a fresh or 1-week-old minimal glucose agar plate. Plates were placed in a $37^{\circ} \mathrm{C}$ incubator for at least $48 \mathrm{~h}$ or even more, after which revertants were counted. All the experiments were carried out in triplicate and results were expressed as the average number of revertants per plate. For each manipulation, negative (spontaneous reversion and mutation in response to DMSO) and positive (response to the standard mutagen) controls were included to ensure the validity of the test.

Most mutagens are also toxic to some extent and consequently the number of revertants usually decreases at higher concentrations. This decrease sometimes leads to the misinterpretation of the mutagenicity data, especially if the toxic chemical is only weakly mutagenic. Waleh et al. (1982) developed an assay for measuring toxicity quantitatively. They have constructed two sets of strains, isogenic with the Ames tester strains except for their his character. One set consists of the his ${ }^{+}$derivatives of the tester strains which are used for measuring the survival of the inoculum cells after exposure to the chemical. The other set is the stable his ${ }^{-}$derivatives of the tester strains which are used for simulating the background growth in the Ames mutagenicity plate test. The percentage survival of the his ${ }^{+}$cells in the inoculum in the presence of the 'filler cells' is used as a measure of the toxic effect of the chemical. Lacking these two sets of strains, we decided to determine the number of viables after treatment with the test compound in order to obtain an approximation of its toxic effect. The procedure is similar to that of mutagenicity. To $2 \mathrm{ml}$ of top agar supplemented with 0.2 $\mathrm{ml}$ of a $25 \mathrm{mM}$ histidine $/ 0.5 \mathrm{mM}$ biotin solution were added: $100 \mu \mathrm{l}$ of the test chemical solution, $100 \mu \mathrm{l}$ of $10^{-6}$ or $10^{-5}$ dilution from an overnight culture of the tester strain and $500 \mu \mathrm{l}$ of $\mathrm{S} 9 \mathrm{mix}$. After shaking, the mixture was spread onto a nutrient agar plate. Plates were incubated at $37^{\circ} \mathrm{C}$ for $24 \mathrm{~h}$ after which viables were counted. As in the mutagenicity test, positive and negative controls were included to ensure the validity of the test. A test compound concentration is considered toxic when it produces a $10 \%$ survival or less.

In order to determine the existence of a mutagenic effect caused by the test compound and quantify it, two methods were used: (i) calculation of the mutation index, and (ii) statistical method based on least-squares linear regression. 
Table IV. Mutagenic evaluation of folpet with TA104

(a) Without $\mathrm{S} 9 \mathrm{mix}$

Assay I

\begin{tabular}{|c|c|c|c|c|c|c|c|c|c|}
\hline \multicolumn{5}{|l|}{ Assay I } & \multicolumn{5}{|l|}{ Assay $\mathrm{II}^{\mathrm{a}}$} \\
\hline $\begin{array}{l}\text { Folpet } \\
(\mu \mathrm{g} / \text { plate })\end{array}$ & $\mathrm{R}$ & MI & Q & v & $\begin{array}{l}\text { Folpet } \\
(\mu \mathrm{g} / \text { plate })\end{array}$ & $\mathrm{R}$ & MI & Q & v \\
\hline 2.5 & $580 \pm 159.10$ & 2 & NM & $6 \times 10^{8}$ & 2.5 & 1012 & 3 & $\mathbf{M}^{+}$ & $3 \times 10^{8}$ \\
\hline 5 & $711 \pm 247.49$ & 2.8 & $\mathrm{M}^{+}$ & $6 \times 10^{8}$ & 5 & 1188 & 3.8 & $\mathrm{M}^{2+}$ & \\
\hline 10 & $726 \pm 542.35$ & 2.9 & $\mathrm{M}^{+}$ & $6 \times 10^{8}$ & 10 & 1272 & 4.1 & $\mathrm{M}^{2+}$ & \\
\hline 20 & $415 \pm 352.14$ & 0.9 & $\mathrm{NM} / \mathrm{T}$ & $4 \times 10^{7}$ & 20 & $1783 \pm 474.27$ & 6.3 & $\mathrm{M}^{3+} / \mathrm{T}$ & $3 \times 10^{7}$ \\
\hline 40 & $267 \pm 166.17$ & 0 & $\mathrm{NM} / \mathrm{T}$ & $10^{7}$ & & & & & \\
\hline SM & $153 \pm 66.47$ & & & $6 \times 10^{8}$ & SM & 238 & & & $3 \times 10^{8}$ \\
\hline DMSO & $278 \pm 43.84$ & 1.8 & NM & $6 \times 10^{8}$ & DMSO & 286 & 1.2 & NM & $3 \times 10^{8}$ \\
\hline MG & 5000 & 30.8 & $\mathrm{M}^{4+}$ & $5 \times 10^{8}$ & MG & 4500 & 17.7 & $\mathrm{M}^{4+}$ & $2 \times 10^{8}$ \\
\hline \multicolumn{5}{|l|}{ Assay IV } & \multicolumn{5}{|l|}{ Assay V } \\
\hline $\begin{array}{l}\text { Folpet } \\
\text { ( } \mu \mathrm{g} / \text { plate })\end{array}$ & $\mathrm{R}$ & MI & Q & v & $\begin{array}{l}\text { Folpet } \\
(\mu \mathrm{g} / \text { plate })\end{array}$ & $\mathrm{R}$ & MI & Q & $\mathrm{v}$ \\
\hline 2.5 & $285 \pm 53.71$ & 1.3 & NM & $10^{7}$ & 0.62 & $617 \pm 111.01$ & 1 & NM & $2 \times 10^{9}$ \\
\hline 5 & $367 \pm 46.70$ & 1.8 & NM & $10^{7}$ & 1.25 & $1208 \pm 101.82$ & 2.9 & $\mathrm{M}^{+}$ & $2 \times 10^{9}$ \\
\hline 10 & $600 \pm 136.47$ & 3.4 & $\mathbf{M}^{+}$ & $10^{7}$ & 2.5 & $1628 \pm 28.28$ & 4.3 & $\mathrm{M}^{2+}$ & $2 \times 10^{9}$ \\
\hline 20 & $464 \pm 128.00$ & 2.5 & $\mathrm{M}^{+} / \mathrm{T}$ & $-2 \times 10^{6}$ & & & & & \\
\hline SM & $150 \pm 13.50$ & & & $10^{7}$ & SM & $306 \pm$ & & & $2 \times 10^{9}$ \\
\hline DMSO & $90 \pm 37.29$ & 0.6 & NM & $10^{7}$ & DMSO & $312 \pm$ & 1 & NM & $2 \times 10^{9}$ \\
\hline MG & 2300 & 14.7 & $\mathrm{M}^{4+}$ & $10^{7}$ & MG & 4250 & 12.8 & $\mathrm{M}^{4+}$ & $2 \times 10^{9}$ \\
\hline
\end{tabular}

(b) With $\mathrm{S} 9 \mathrm{mix}$

Assay II $^{\mathrm{a}}$

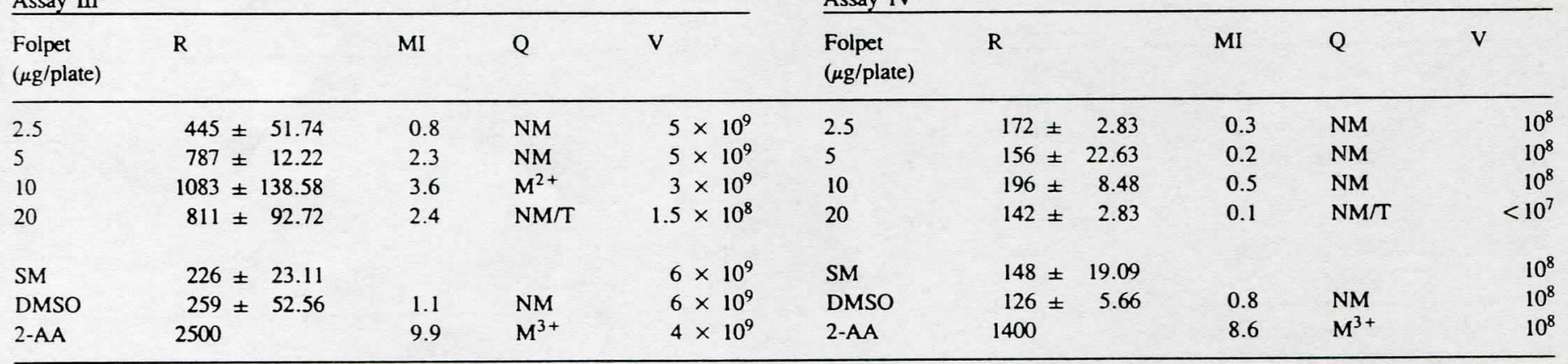

Legend as Table III.

(i) Calculation of the mutation index. The mutation index is defined as the ratio between induced and spontaneous revertants (Mattern, 1981).

$$
\begin{gathered}
M I=\frac{T-C}{C} \\
M I=\text { mutation index } \\
T=\text { revertants/treated plate } \\
C=\text { revertants/control plate }
\end{gathered}
$$

A concentration of the test compound is considered mutagenic when the mutation index is 2.5 .

(ii) Statistical method based on least squares linear regression. The method used is based on the one described by Moore and Felton (1983) and the calculations were made following Sokal and Rohlf's model (Sokal and Rohlf, 1980). The viables count as well as the decrease in the number of revertants give an idea of the test compound concentrations which are toxic for the bacterium and which must therefore be eliminated in order to avoid any mutagenicity/toxicity interaction. At first, a model I analysis of variance (ANOVA) of data is carried out. If ANOVA is not significant, the tested compound is considered non-mutagenic, but if ANOVA is significant, an analysis of regression is carried out in order to prove-in the case of significance-that there is a linear relationship between dose and response. and then the slope is calculated and used as a measure of the mutagenic effect.
If the analysis of regression is not significant, the mutagenic effect cannot be calculated and in this case another method would have to be used.

The mutagenic potency has been expressed as number of induced revertants/nmol of product, taking the number of revertants from the top level of the linear par of dose-response curves. When there were several assays with the same product and with the same strain adjusting to a line, the assay choice always was the assay with the greatest slope.

Finally, a two-way ANOVA with replication (Sokal and Rohlf, 1980) was used to determine the influence of $S 9$ mix on the mutagenic activity observed.

\section{Results}

\section{TA104}

Results are summarized in Table II. According to the mutation index, only captan and folpet were mutagenic. Table III shows the mutagenic evaluation of captan and Table IV that of folpet.

Four assays have been performed in the absence of S9 mix with both compounds. The range of concentrations evaluated was from 0.62 to $20 \mu \mathrm{g} /$ plate for captan, and from 0.62 to $40 \mu \mathrm{g} /$ plate for folpet. In all the assays performed with both compounds, there was a dose-related increase in mutant colonies at non-toxic doses used. The toxic concentration of captan was $10 \mu \mathrm{g} /$ plate and that 


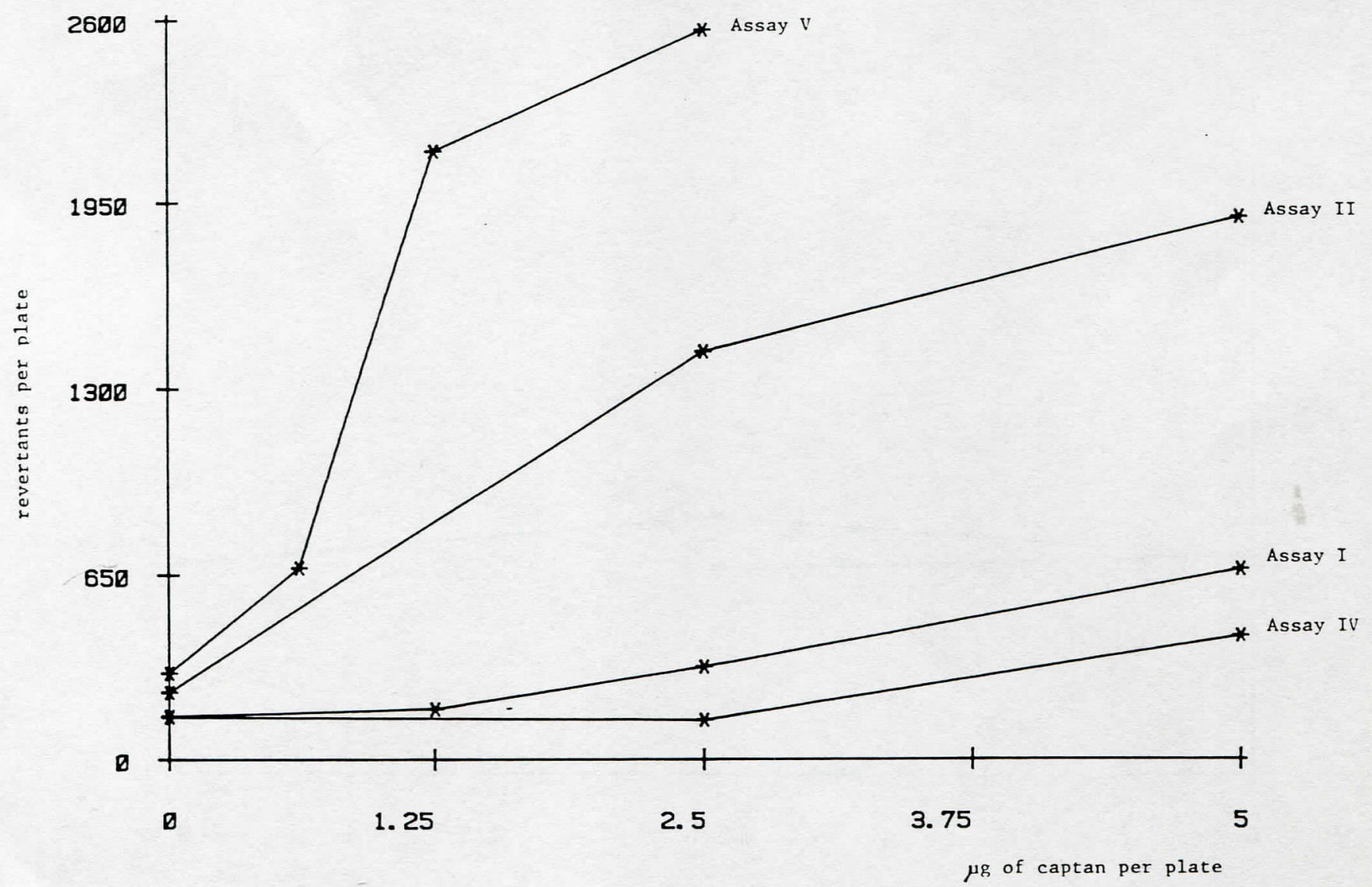

Fig. 1. Dose-effect relationship for captan with Salmonella typhimurium TA104.

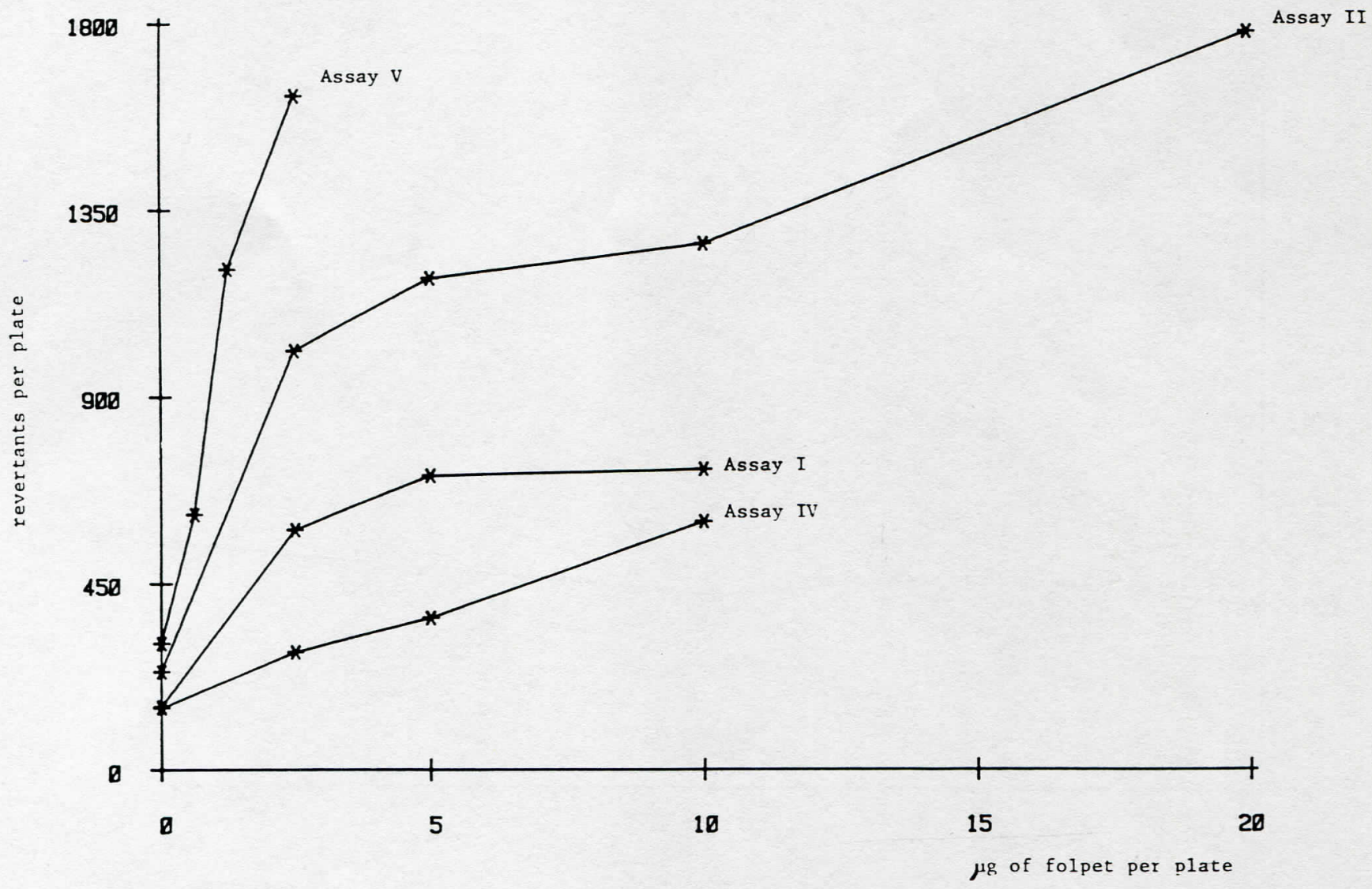

Fig. 2. Dose-effect relationship for folpet with Salmonella typhimurium TA104. 


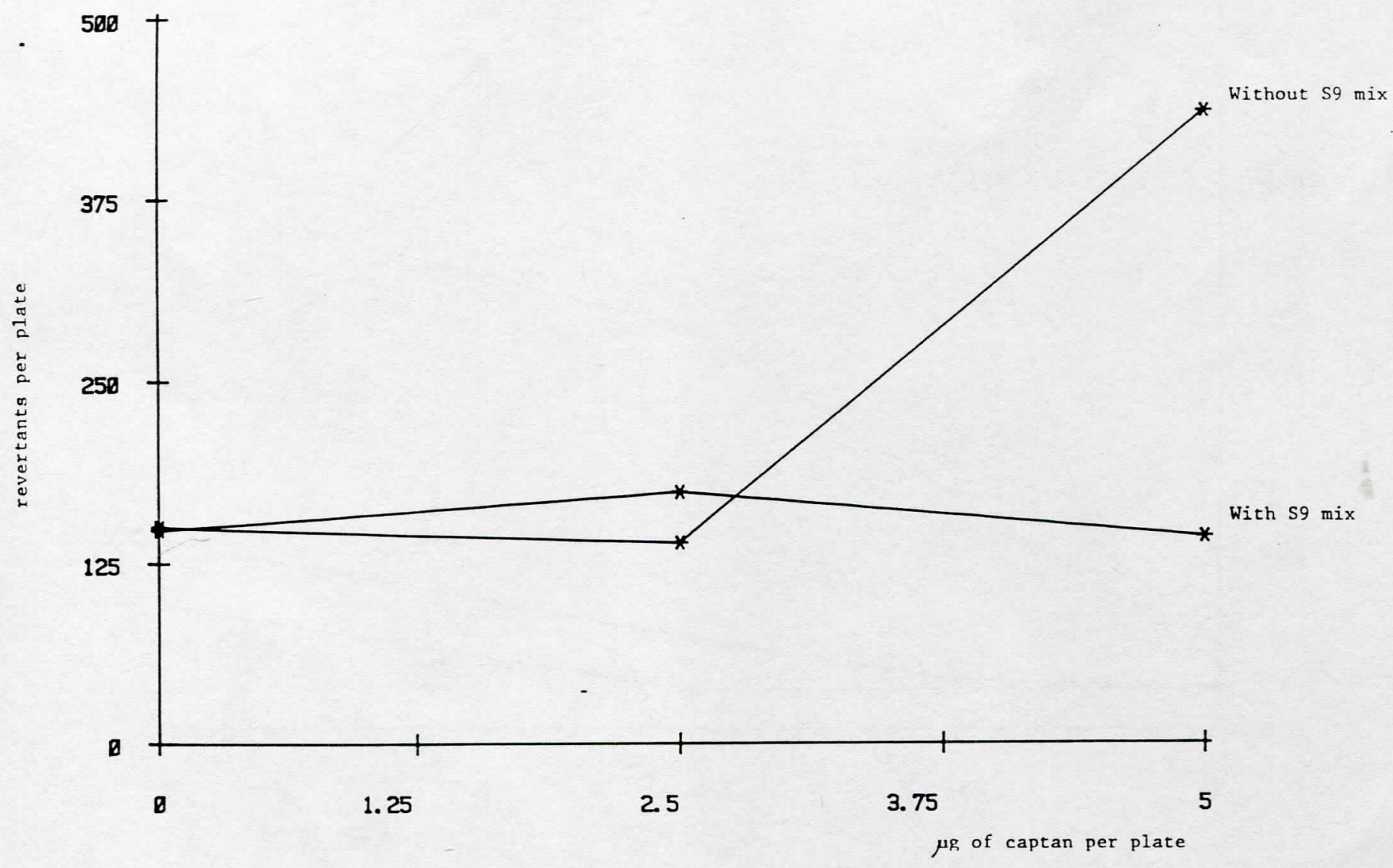

Fig. 3. Dose-effect relationship for captan with Salmonella typhimurium TA104 corresponding to Assay IV.

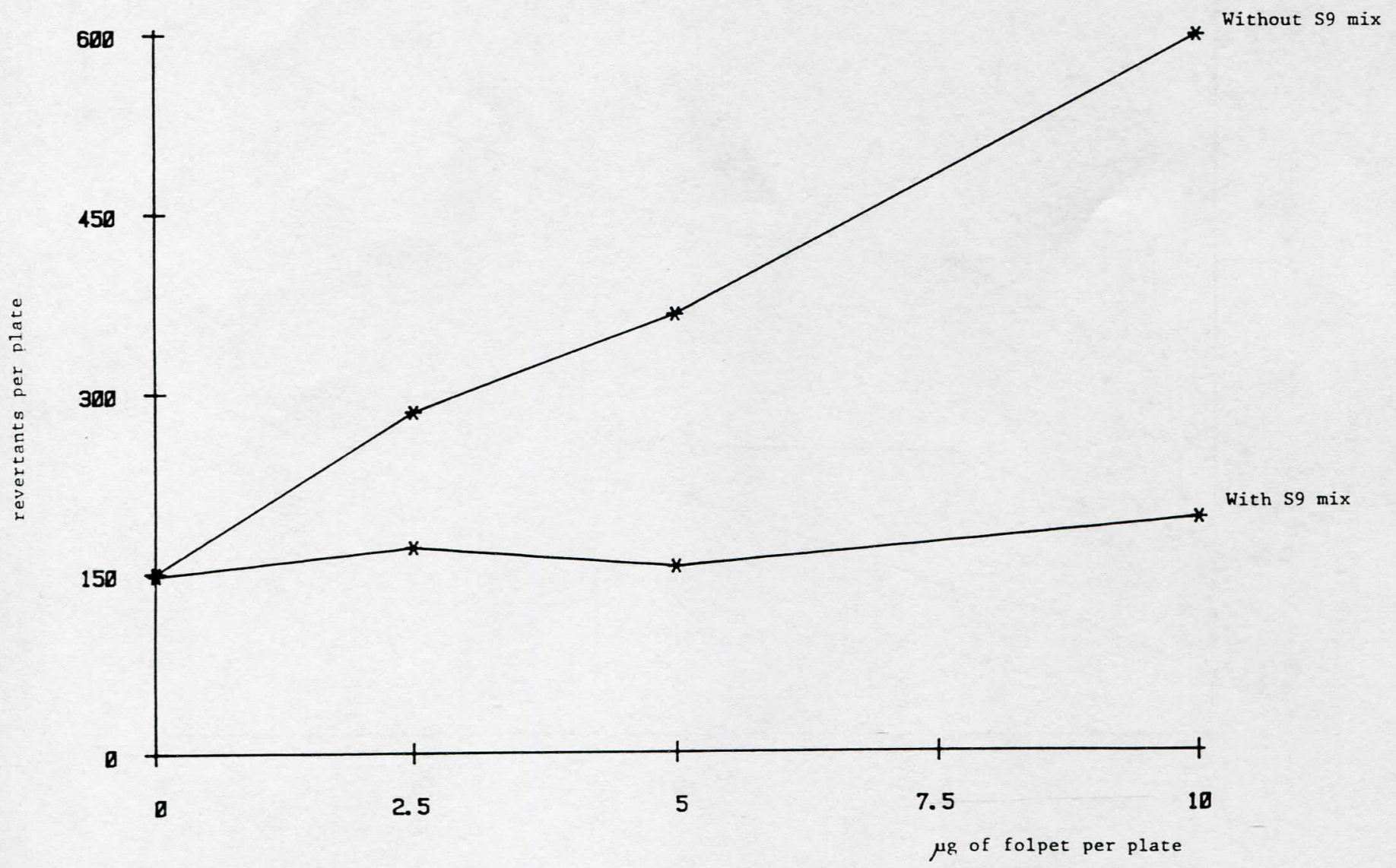

Fig. 4. Dose-effect relationship for folpet with Salmonella typhimurium TA104 corresponding to Assay IV. 
Table V. Influence of the inoculum size in the mutagenicity of captan and folpet to TA 104

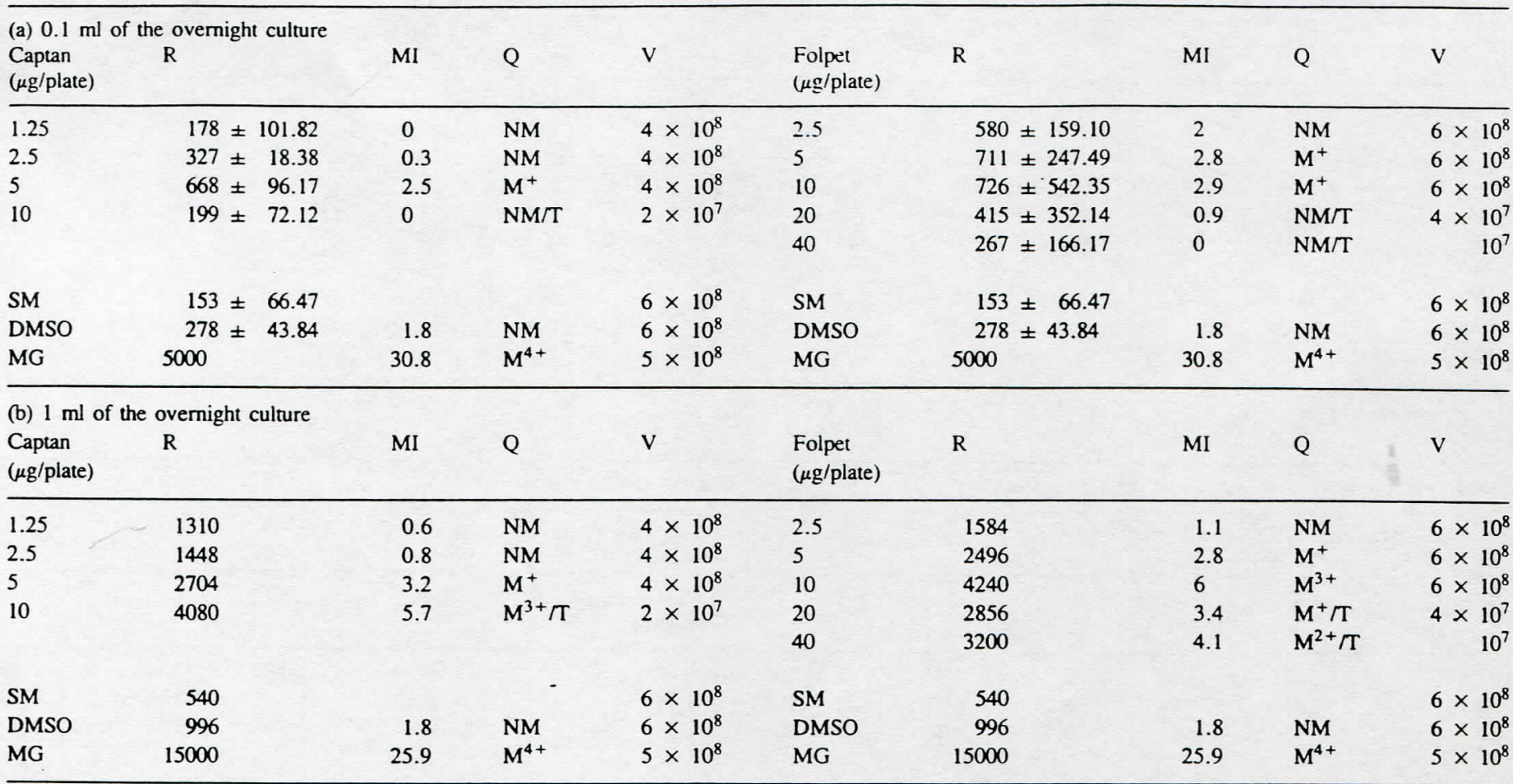

Legend as Table III

Table VI. Influence of the minimal glucosa agar plates used in the mutagenicity of captan to TA104

\begin{tabular}{|c|c|c|c|c|c|c|c|c|c|}
\hline \multicolumn{5}{|c|}{ (a) Fresh plates } & \multicolumn{5}{|c|}{ (b) Old plates } \\
\hline $\begin{array}{l}\text { Captan } \\
(\mu \mathrm{g} / \text { plate })\end{array}$ & $\mathbf{R}$ & MI & Q & v & $\begin{array}{l}\text { Captan } \\
\text { ( } \mu \mathrm{g} / \text { plate })\end{array}$ & $\mathrm{R}$ & MI & Q & V \\
\hline 2.5 & $1432 \pm 452.55$ & 4.8 & $\mathrm{M}^{2+}$ & $3 \times 10^{8}$ & 2.5 & 624 & 2.1 & NM & $3 \times 10^{8}$ \\
\hline 5 & 1904 & 6.7 & $\mathrm{M}^{3+}$ & $10^{8}$ & 5 & 812 & 3 & $\mathrm{M}^{+}$ & $10^{8}$ \\
\hline 10 & 1692 & 5.9 & $\mathrm{M}^{3+} / \mathrm{T}$ & $<10^{7}$ & 10 & 284 & 0.4 & $\mathrm{NM} / \mathrm{T}$ & $<10^{7}$ \\
\hline 20 & 352 & 0.3 & $\mathrm{NM} / \mathrm{T}$ & $2 \times 10^{6}$ & 20 & $O(s)$ & & $\mathrm{T}$ & $2 \times 10^{6}$ \\
\hline SM & 238 & & & $3 \times 10^{8}$ & SM & 203 & & & $3 \times 10^{8}$ \\
\hline DMSO & 286 & 1.2 & NM & $3 \times 10^{8}$ & DMSO & 196 & 1 & NM & $3 \times 10^{8}$ \\
\hline MG & 4500 & 17.7 & $\mathbf{M}^{4+}$ & $2 \times 10^{8}$ & MG & 3200 & 14.7 & $\mathrm{M}^{4+}$ & $2 \times 10^{8}$ \\
\hline
\end{tabular}

Legend as Table III.

MMS = mutation in response to methyl methane sulphonate.

of folpet was $20 \mu \mathrm{g} /$ plate since these concentrations produced a survival of $\leq 10 \%$ in most assays. However, there was variability probably due to differences in spontaneous reversion and the number of bacteria plated. The higher the spontaneous reversion, then the higher the captan- and folpet-induced reversion; when spontaneous reversion was similar the higher the number of bacteria plated, then the higher captan- and folpetinduced reversion (Figures 1 and 2; Tables III and IV).

Two assays have been performed in the presence of S9 mix for both compounds and the range of concentrations evaluated was from 2.5 to $20 \mu \mathrm{g} /$ plate. The toxic concentration of both captan and folpet was $20 \mu \mathrm{g} /$ plate. The differences from one assay to another again seem to be due both spontaneous reversion and the number of bacteria plated (Tables III and IV). The mutagenic activity of both compounds decreased in the presence of $S 9$ mix, so they are considered direct mutagens (Figures 3 and 4).

The influence of the inoculum size in the mutagenicity of both captan and folpet is shown in Table V. When $1 \mathrm{ml}$ of the overnight culture was used to perform the test, we did not get a better mutagenic response than when $0.1 \mathrm{ml}$ of the overnight culture was used but a clearer dose-response relationship was observed. However, the minimum level of detection of mutagenicity was the same, irrespective of the inoculum size.

On the other hand, when 'old' minimal glucose agar plates were used to perform the test, the mutagenic effect caused by captan decreased (Table VI).

The minimum mutagenic concentration was $1.25 \mu \mathrm{g} /$ plate for both captan and folpet. A concentration range could be established with dose-response ranging from 1.25 to $5 \mu \mathrm{g} /$ plate for captan and from 1.25 to $10 \mu \mathrm{g} /$ plate for folpet, the difference being due to the higher toxicity of captan. When there were at least three concentrations of compound that were non-toxic to bacteria, the statistical analysis was performed on data (Table II). The mutagenic potency calculated for the assay with the greatest slope was established at 106.63 revertants/nmol for captan and 156.91 revertants/nmol for folpet. 
Table VII. Mutagenic evaluation of captafol with TA104

\begin{tabular}{|c|c|c|c|c|c|c|c|c|c|c|c|c|c|c|}
\hline \multicolumn{5}{|c|}{$\begin{array}{l}\text { (a) Without } \mathrm{S} 9 \mathrm{mix} \\
\text { Assay I }\end{array}$} & \multicolumn{5}{|l|}{ Assay II $^{\mathrm{a}}$} & \multicolumn{5}{|c|}{$\begin{array}{l}\text { (b) With } \mathrm{S} 9 \mathrm{mix} \\
\text { Assay } \mathrm{III}^{\mathrm{a}}\end{array}$} \\
\hline $\begin{array}{l}\text { Captafol } \\
(\mu g / \text { plate })\end{array}$ & $\mathrm{R}$ & MI & Q & V & $\begin{array}{l}\text { Captafol } \\
(\mu \mathrm{g} / \text { plate })\end{array}$ & $\mathrm{R}$ & MI & Q & V & $\begin{array}{l}\text { Captafol } \\
(\mu \mathrm{g} / \text { plate })\end{array}$ & $\mathrm{R}$ & MI & Q & V \\
\hline 0.16 & $288 \pm 57.98$ & 0.06 & NM & $6 \times 10^{8}$ & 0.16 & $383 \pm 118.09$ & 0.4 & NM & $2 \times 10^{8}$ & 0.16 & $267 \pm 12.12$ & 0.03 & NM & $5 \times 10^{9}$ \\
\hline 0.31 & $276 \pm 69.30$ & 0 & NM & $3 \times 10^{8}$ & 0.31 & $373 \pm 78.94$ & 0.4 & NM & $6 \times 10^{7}$ & 0.31 & $215 \pm 27.23$ & 0 & NM & $4 \times 10^{9}$ \\
\hline 0.62 & $284 \pm 96.17$ & 0.03 & $\mathrm{NM} / \mathrm{T}$ & $9 \times 10^{6}$ & 0.62 & $414 \pm 37.48$ & 0.5 & $\mathrm{NM} / \mathrm{T}$ & $5 \times 10^{6}$ & 0.62 & $255 \pm 18.90$ & 0 & NM & $7 \times 10^{8}$ \\
\hline SM & $153 \pm 66.47$ & & & $6 \times 10^{8}$ & $\mathrm{SM}$ & 238 & & & $3 \times 10^{8}$ & SM & $226 \pm 23.11$ & & & $6 \times 10^{9}$ \\
\hline DMSO & $278 \pm 43.84$ & 1.8 & NM & $6 \times 10^{8}$ & DMSO & 286 & 1.2 & NM & $3 \times 10^{8}$ & DMSO & $259 \pm 52.56$ & 1.1 & NM & $6 \times 10^{9}$ \\
\hline MG & 5000 & 30.8 & $\mathrm{M}^{4+}$ & $5 \times 10^{8}$ & MG & 4500 & 17.7 & $\mathrm{M}^{4+}$ & $2 \times 10^{8}$ & $2-\mathrm{AA}$ & 2500 & 9.9 & $\mathrm{M}^{3+}$ & $4 \times 10^{9}$ \\
\hline
\end{tabular}

Legend as Table III.

Table VIII. Mutagenic evaluation of dichlofluanid with TA104

\begin{tabular}{|c|c|c|c|c|c|c|c|c|c|}
\hline \multicolumn{5}{|c|}{$\begin{array}{l}\text { (a) Without } \mathrm{S9} \text { mix } \\
\text { Assay } \text { II }^{\mathrm{a}}\end{array}$} & \multicolumn{5}{|c|}{$\begin{array}{l}\text { (b) With } \mathrm{S} 9 \mathrm{mix} \\
\text { Assay } \mathrm{III}^{\mathrm{a}}\end{array}$} \\
\hline $\begin{array}{l}\text { Dichlofluanid } \\
\text { ( } \mu \text { g/plate) }\end{array}$ & $\mathbf{R}$ & MI & Q & v & $\begin{array}{l}\text { Dichlofluanid } \\
\text { ( } \mu \text { g/plate) }\end{array}$ & $\mathrm{R}$ & MI & Q & $\mathrm{V}$ \\
\hline 0.62 & $258 \pm 11.53$ & 0 & NM & $3 \times 10^{8}$ & 0.62 & $263 \pm 4.16$ & 0.02 & NM & $5 \times 10^{9}$ \\
\hline 1.25 & $306 \pm 36.94$ & 0.08 & NM & $-\quad 2 \times 10^{8}$ & 1.25 & $227 \pm 30.61$ & 0 & NM & $4 \times 10^{9}$ \\
\hline 2.5 & $397 \pm 115.31$ & 0.5 & NM & $6 \times 10^{7}$ & 2.5 & $231 \pm 26.56$ & 0 & $\mathrm{NM}$ & $4 \times 10^{9}$ \\
\hline SM & 238 & & & $3 \times 10^{8}$ & SM & $226 \pm 23.11$ & & & $6 \times 10^{9}$ \\
\hline DMSO & 286 & 1.2 & NM & $3 \times 10^{8}$ & DMSO & $259 \pm 52.56$ & 1.1 & NM & $6 \times 10^{9}$ \\
\hline MG & 4500 & 17.7 & $\mathrm{M}^{4+}$ & $2 \times 10^{8}$ & $2-A A$ & 2500 & 9.9 & $\mathrm{M}^{3+}$ & $4 \times 10^{9}$ \\
\hline
\end{tabular}

Legend as Table III.

Table IX. Mutagenic evaluation of tetrahydrophthalimide with TA104

(a) Without $S 9$ mix Assay I

Tetrahydro- $\mathrm{R}$ phthalimide ( $\mu \mathrm{g} /$ plate)

$$
80
$$$$
80
$$

$40 \quad 457 \pm 29.70 \quad 1.2 \quad \mathrm{NM} 6 \times 10^{8} 80$

$413 \pm 103.940 .9$ NM $6 \times 10^{8} 160$

$$
320
$$

$\begin{array}{lrrrrrrr}\text { SM } & 153 \pm & 66.47 & & & 6 \times 10^{8} & \text { SM } & 238 \\ \text { DMSO } & 278 \pm & 43.84 & 1.8 & \text { NM } & 6 \times 10^{8} & \text { DMSO } & 286 \\ \text { MG } & 5000 & & 30.8 & M^{4+} 5 \times 10^{8} & \text { MG } & 4500\end{array}$

Legend as Table III.

The remaining chemicals were non-mutagenic according to the mutation index (Tables VII-X). ANOVA was not significant in most assays. In one case, however, there was a significance but the variations due to the dose did not adjust to a regression line; therefore the only method used to determine the mutagenic effect was the mutation index calculation which showed the non-mutagenicity of these compounds (Table II).

As regards toxicity, the following sequence can be seen: thiazolidine-4-carboxylic acid $=$ tetrahydrophthalimide $<$ folpet $<$ captan < dichlofluanid < captafol.

\section{TA102}

The results are summarized in Table XI. Captafol was the only clearly mutagenic compound. Table XII shows the mutagenic evaluation of captafol. Three concentrations were evaluated: 0.16 , (b) With $\mathrm{S} 9 \mathrm{mix}$ Assay III ${ }^{\mathrm{a}}$

Tetrahydro- $R \quad$ MI Q V
phthalimide $(\mu \mathrm{g} /$ plate)
0.31 and $0.62 \mu \mathrm{g} /$ plate. In the two assays without $\mathrm{S} 9 \mathrm{mix}$, there was a dose-related increase in the number of mutant colonies; however, there were differences between assays. The lower spontaneous reversion showed the higher captafol-induced reversion (Figure 5). In the presence of S9 mix, the mutagenic activity of captafol decreased, so captafol is considered a direct mutagen (Figure 6).

The minimum mutagenic concentration was $0.31 \mu \mathrm{g} /$ plate. A concentration range could be established with dose-response ranging from 0.31 to $0.62 \mu \mathrm{g} /$ plate. The statistical analysis was performed on data (Table XII) and the mutagenic potency calculated for the assay with the greatest slope was established at 537.64 revertants/nmol (Table XI).

The remaining chemicals were non-mutagenic according to the mutation index (Tables XIII-XVII) and the variations due to 
Table X. Mutagenic evaluation of thiazolidine-4-carboxylic acid

\begin{tabular}{|c|c|c|c|c|c|c|c|c|c|}
\hline \multicolumn{5}{|l|}{$\begin{array}{l}\text { (a) Without } \mathrm{S} 9 \mathrm{mix} \\
\text { Assay } \mathrm{I}^{\mathrm{a}}\end{array}$} & \multicolumn{5}{|l|}{$\begin{array}{l}\text { (b) With } S 9 \mathrm{mix} \\
\text { Assay } \mathrm{II}^{\mathrm{a}}\end{array}$} \\
\hline $\begin{array}{l}\text { Thiazolidine-4-carboxylic } \\
\text { acid ( } \mu \text { g/plate) }\end{array}$ & $\mathrm{R}$ & MI & Q & V & $\begin{array}{l}\text { Thiazolidine-4-carboxylic } \\
\text { acid ( } \mu \mathrm{g} / \text { plate) }\end{array}$ & $\mathrm{R}$ & MI & Q & v \\
\hline 80 & $370 \pm 71.00$ & 0.3 & NM & $3 \times 10^{8}$ & 80 & 226 & 0 & NM & $6 \times 10^{9}$ \\
\hline 160 & $350 \pm 2.83$ & 0.3 & NM & $3 \times 10^{8}$ & 160 & $166 \pm 41.01$ & 0 & NM & $6 \times 10^{9}$ \\
\hline 320 & $341 \pm 34.08$ & 0.2 & NM & $3 \times 10^{8}$ & 320 & $202 \pm 31.43$ & 0 & NM & $6 \times 10^{9}$ \\
\hline 500 & $332 \pm 22.63$ & 0.2 & NM & $2 \times 10^{8}$ & 500 & $181 \pm 12.22$ & 0 & NM & $5 \times 10^{9}$ \\
\hline SM & 238 & & & $3 \times 10^{8}$ & SM & $226 \pm 23.11$ & & & $6 \times 10^{9}$ \\
\hline DMSO & 286 & 1.2 & NM & $3 \times 10^{8}$ & DMSO & $259 \pm 52.56$ & 1.1 & NM & $6 \times 10^{9}$ \\
\hline MG & 4500 & 17.7 & $\mathrm{M}^{4+}$ & $2 \times 10^{8}$ & $2-A A$ & 2500 & 9.9 & $\mathbf{M}^{3+}$ & $4 \times 10^{9}$ \\
\hline
\end{tabular}

Legend as Table III.

Table XI. Mutagenic evaluation with TA102

\begin{tabular}{|c|c|c|c|c|c|c|c|c|c|c|c|c|c|}
\hline & & \multicolumn{2}{|l|}{ Captan } & \multicolumn{2}{|l|}{ Folpet } & \multicolumn{2}{|l|}{ Captafol } & \multicolumn{2}{|c|}{ Dichlofluanid } & \multicolumn{2}{|c|}{$\begin{array}{l}\text { Tetrahydro- } \\
\text { phthalimide }\end{array}$} & \multicolumn{2}{|c|}{$\begin{array}{l}\text { Thiazolidine-4- } \\
\text { carboxylic acid }\end{array}$} \\
\hline & & I & II & I & II & I & II & I & II & I & II & I & II \\
\hline $\begin{array}{l}\text { Range of [] } \\
\text { evaluated }\end{array}$ & $-S 9+$ & $2.5-20$ & $2.5-20$ & $2.5-20$ & $2.5-20$ & $0.16-0.62$ & $0.16-0.62$ & $0.62-2.5$ & $0.62-2.5$ & $80-500$ & $80-500$ & $80-500$ & $80-500$ \\
\hline $\begin{array}{l}\text { in } \mu \mathrm{g} / \text { plate } \\
\text { Range of mutagenic }\end{array}$ & $+\mathrm{S} 9+$ & & $2.5-20$ & & $2.5-20$ & & $0.16-0.62$ & & $0.62-2.5$ & & $80-500$ & & $80-500$ \\
\hline $\begin{array}{l}\text { concentrations } \\
\text { according to the } \\
\text { mutation index } \\
\text { in } \mu \mathrm{g} / \text { plate }\end{array}$ & $\begin{array}{l}-\mathrm{S} 9+ \\
+\mathrm{S} 9+\end{array}$ & & & & & 0.62 & $\begin{array}{l}0.31-0.62 \\
0.62\end{array}$ & & & & & & \\
\hline ANOVA I & $-s 9+$ & & & NS & $* * *$ & ** & $* * *$ & & & $* *$ & NS & NS & $* * *$ \\
\hline & $+\mathrm{S} 9+$ & & NS & & $* * *$ & & $* * *$ & & & & $* * *$ & & * \\
\hline Regression & $-\mathrm{S} 9+$ & & & & NS & $* * *$ & $* *$ & & & NS & & & * \\
\hline analysis & $+\mathrm{S} 9+$ & & & & NS & & ** & & & & NS & & NS \\
\hline $\begin{array}{l}\text { Slope of regression } \\
\text { line }\end{array}$ & $\begin{array}{l}-\mathrm{S} 9+ \\
+\mathrm{S} 9+\end{array}$ & & & & & 1039.36 & $\begin{array}{r}1617.65 \\
774.01\end{array}$ & & & & & & 0.17 \\
\hline $\begin{array}{l}\text { Mutagenic potency } \\
\text { in rev/nmol }\end{array}$ & & & & & & & 537.64 & & & & & & \\
\hline Two-way ANOVA & & & & & NS & & $* * *$ & & & & NS & & NS \\
\hline with replication & & & & & $* * *$ & & $* * *$ & & & & NS & & NS \\
\hline & & & & & $* * *$ & & $* * *$ & & & & $* * *$ & & $* * *$ \\
\hline
\end{tabular}

I and II refer to different assays.

Revertants were counted after 6 days.

Table XII. Mutagenic evaluation of captafol with TA102

(a) Without $\mathrm{S} 9 \mathrm{mix}$

Assay I ${ }^{\mathrm{a}}$

Captafol R

( $\mu \mathrm{g} /$ plate $)$

\subsection{6}

0.31

0.62

SM

DMSO

$122 \pm 6.36$
$164 \pm 8.48$

MMS
$341 \pm$
$403 \pm$
$790 \pm$
$122 \pm$
$164 \pm$
2704

Legend as Table III.

MMS = mutation in response to methyl methane sulphonate.

the dose, if present, either did not adjust to a regression line or, if they did, the slope was too small (Table XI) and it may be considered that captan, folpet, dichlofluanid, tetrahydro- (b) With $\mathrm{S} 9 \mathrm{mix}$

Assay II

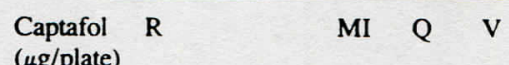
( $\mu \mathrm{g} /$ plate)

$\begin{array}{lllll}0^{7} & 0.16 & 195 \pm 13.05 & 0.3 & \text { NM } 2 \times 10^{9}\end{array}$

$10^{7} \quad 0.31 \quad 324 \pm 112.43 \quad 1.2 \quad$ NM $2 \times 10^{9}$

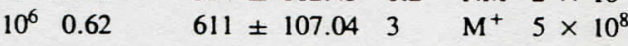

$10^{7} \mathrm{SM} \quad 151 \pm 23.43 \quad 2 \times 10^{9}$

$10^{7}$ DMSO $147 \pm 26.501$ NM $2 \times 10^{9}$

$<10^{6} \quad 2$-AA $\quad 473 \quad 2.1 \quad$ NM $3 \times 10^{8}$ phthalimide and thiazolidine-4-carboxylic acid were nonmutagenic to TA 102 under own test conditions.

As regards toxicity, the following sequence can be seen: 


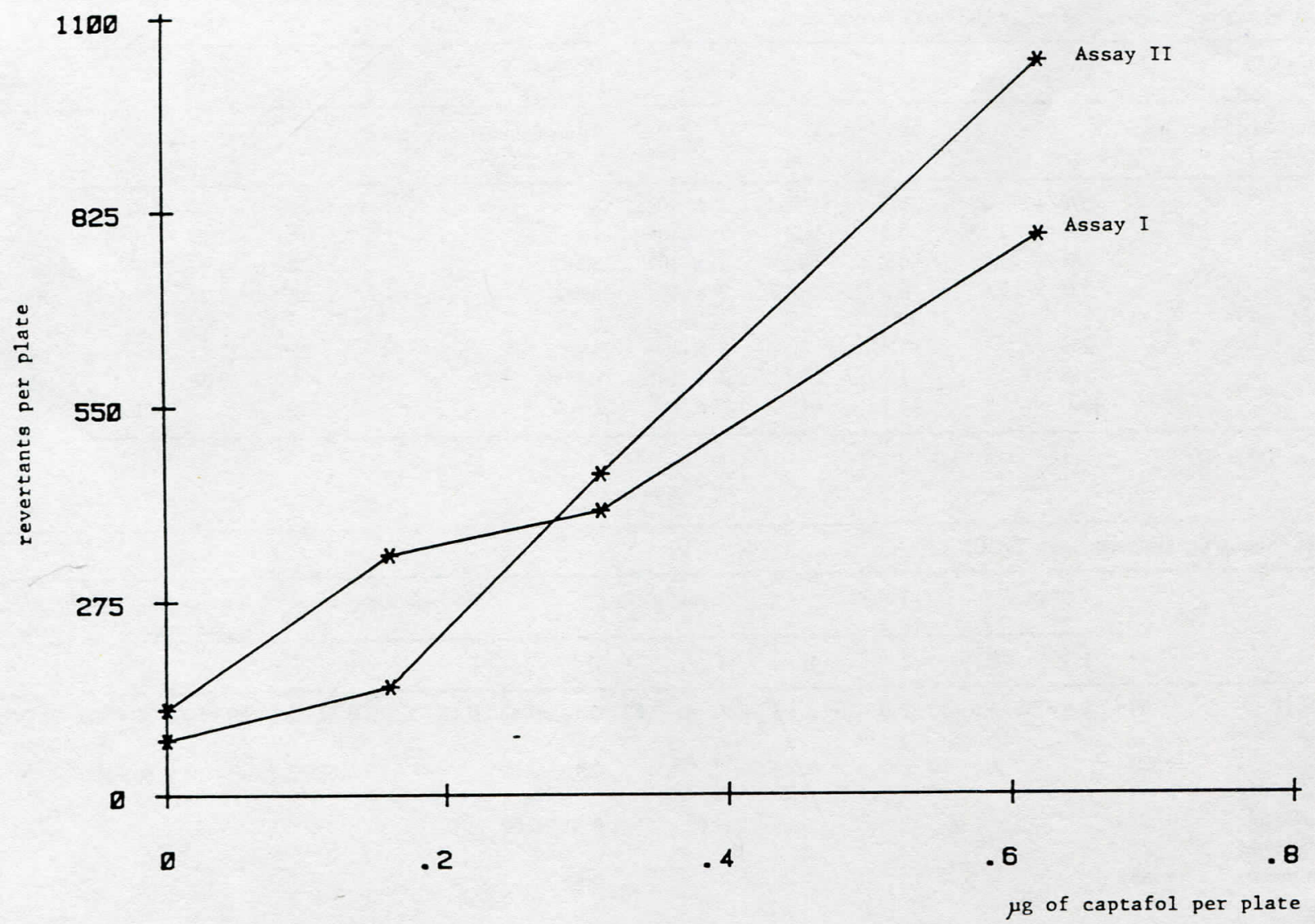

Fig. 5. Dose-effect relationship for captafol with Salmonella typhimurium TA102.

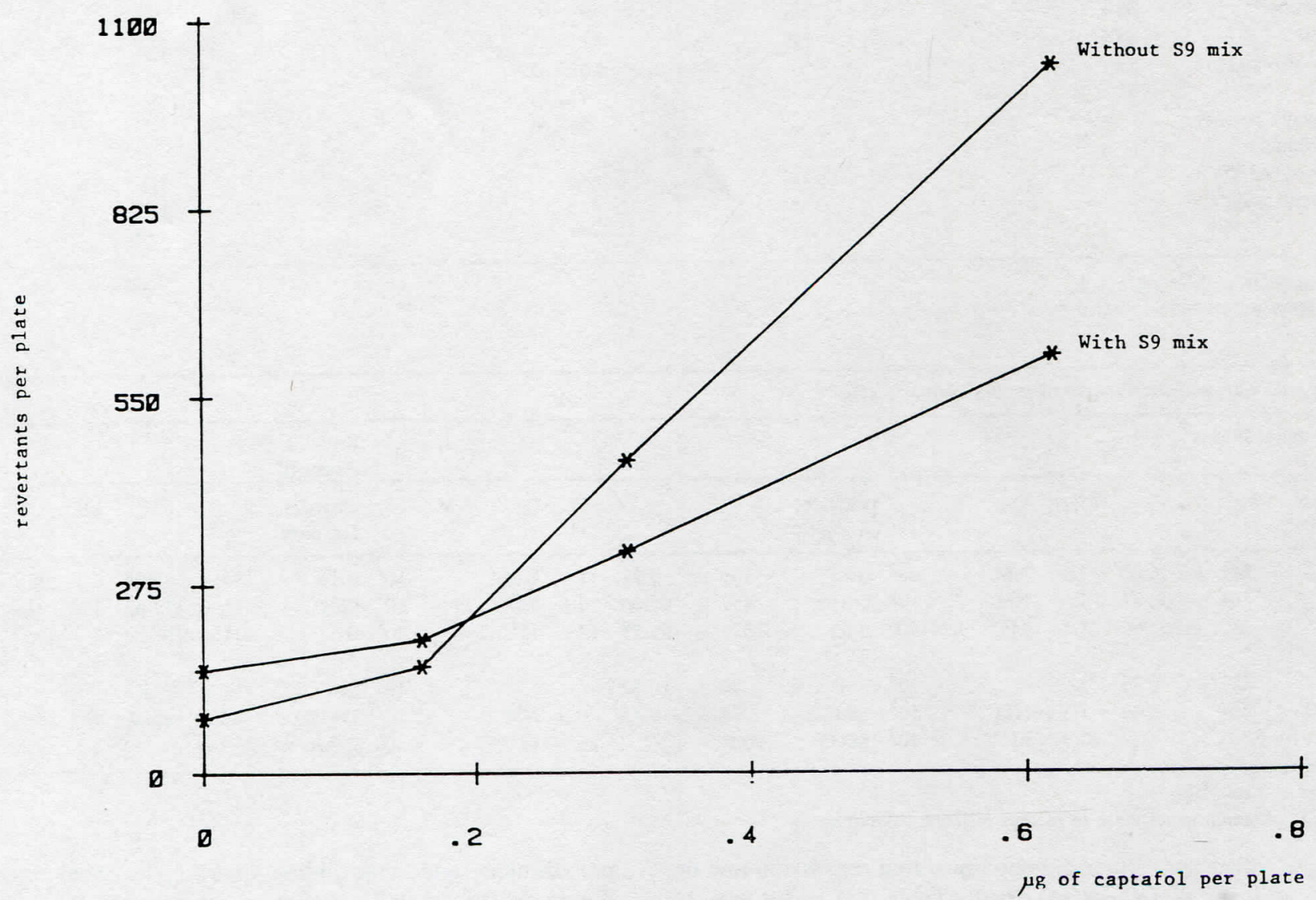

Fig. 6. Dose-effect relationship for captafol with Salmonella typhimurium TA102 corresponding to Assay II. 
Table XIII. Mutagenic evaluation of dichlofluanid with TA104

\begin{tabular}{|c|c|c|c|c|c|c|c|c|c|c|c|c|c|c|c|c|}
\hline \multicolumn{6}{|c|}{$\begin{array}{l}\text { (a) Without } 59 \text { mix } \\
\text { Assay } \mathrm{I}^{\prime \prime}\end{array}$} & \multicolumn{6}{|l|}{ Assay $11^{\perp}$} & \multicolumn{5}{|c|}{$\begin{array}{l}\text { (b) With Sy mix } \\
\text { Assay } \text { II }^{\text {a }}\end{array}$} \\
\hline $\begin{array}{l}\text { Dichlofluanid } \\
\text { ( } \mu \mathrm{g} / \text { plate })\end{array}$ & $\mathrm{R}$ & MI & $Q$ & V & & $\begin{array}{l}\text { Dichlofluanid } \\
(\mu \mathrm{g} / \text { platc) }\end{array}$ & $\mathrm{R}$ & MI & Q & V & & $\begin{array}{l}\text { Dichlofluanid } \\
\text { ( } \mu \mathrm{g} / \text { plate })\end{array}$ & $\mathrm{R}$ & MI & Q & v \\
\hline 0.62 & $311 \pm 2.83$ & 1.2 & NM & & $<10^{7}$ & 0.62 & $133 \pm 10.07$ & 0.7 & NM & & $10^{7}$ & 0.62 & $181 \pm 29.28$ & 0.2 & NM & $2 \times 10^{4}$ \\
\hline 1.25 & $3(1) 3$ & 1.1 & NM & & $<10^{7}$ & 1.25 & $1.34 \pm 2.83$ & 0.2 & NM & & $10^{7}$ & 1.25 & $188 \pm 48.87$ & 0.3 & NM & $2 \times 10^{4}$ \\
\hline 2.5 & 17.3 & 0.07 & $\mathrm{NM} / \mathrm{T}$ & & $10^{6}$ & 2.5 & $1(x)$ & () & NM & 3 & $\times 10^{6}$ & 2.5 & $106 \pm 5.66$ & () & $\mathrm{NM} / \mathrm{T}$ & $2 \times 10^{x}$ \\
\hline SM & $122 \pm 6.36$ & & & & $10)^{7}$ & SM & $80 \pm 19.52$ & & & & $10^{7}$ & SM & $1.51 \pm 23.43$ & & & $2 \times 10^{\prime \prime}$ \\
\hline DMSO & $164 \pm 8.48$ & 1.3 & NM & & $10^{7}$ & DMSO & $74 \pm 18.45$ & 0.9 & NM & & $10^{7}$ & DMSO & $147 \pm 26.5()$ & 1 & NM & $2 \times 10^{4}$ \\
\hline MMS & 2704 & 20.7 & $\mathrm{M}^{++}$ & 2 & $\times 10^{6}$ & MMS & $2(1) 8()$ & 25 & $\mathrm{M}^{4+} / \mathrm{T}$ & & $<10^{\circ}$ & $2-A A$ & 473 & 2.1 & NM & $3 \times 10^{x}$ \\
\hline
\end{tabular}

Legend as Table III

MMS = mutation in response to methyl methane sulphonate

Table XIV. Mutagenic evaluation of captan with TA102

(a) Without $S 9$ mix

Assay $\mathrm{I}^{\mathrm{a}}$

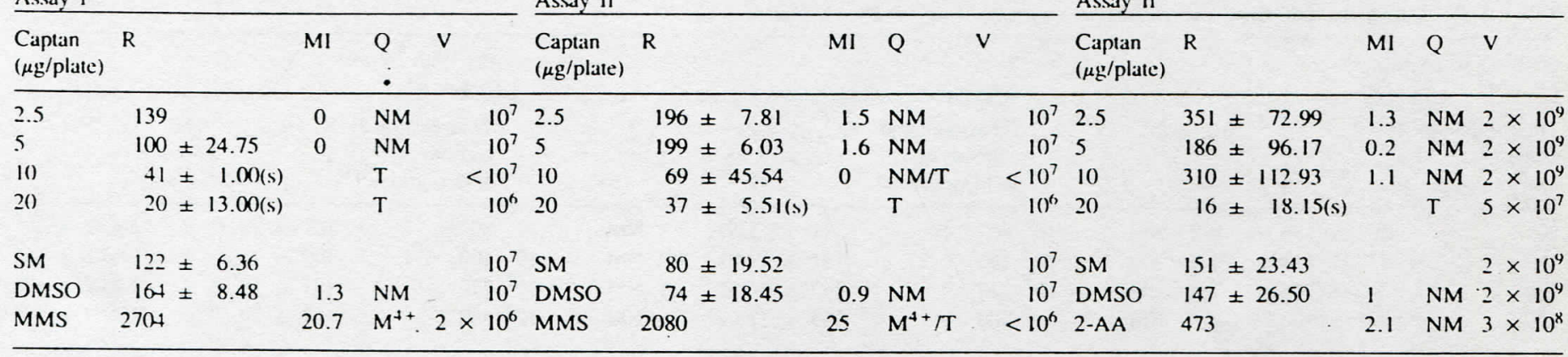

Legend as Table III.

MMS = mutation in response to methyl methane sulphonate.

Table XV. Mutagenic cvaluation of folpet with TA102

(a) Without $\mathrm{S} 9$ mix

Assay $1^{4}$

\begin{tabular}{|c|c|c|c|c|c|c|c|}
\hline $\begin{array}{l}\text { Folpet } \\
\text { ( } \mu \text { g/platc) }\end{array}$ & $\mathrm{R}$ & MI & Q & V & & $\begin{array}{l}\text { Folpet } \\
\text { ( } \mu \mathrm{g} / \text { plate })\end{array}$ & $\mathbf{R}$ \\
\hline 2.5 & $331 \pm 89.32$ & 1.4 & NM & & $10^{7}$ & 2.5 & $208 \pm$ \\
\hline 5 & $320 \pm 11.31$ & 1.3 & NM & & $10^{7}$ & 5 & $225 \pm 3$ \\
\hline 10 & $339 \pm 94.85$ & 1.4 & NM & & $10^{7}$ & 10 & $243 \pm 6$ \\
\hline 20 & $94 \pm 20.50$ & 0 & $\mathrm{NM} / \mathrm{T}$ & & $10^{h}$ & 20 & $152 \pm 1$ \\
\hline SM & $122 \pm 6.36$ & & & & $10^{7}$ & SM & $80 \pm 1$ \\
\hline DMSO & $164 \pm 8.48$ & 1.3 & NM & & $10^{7}$ & DMSO & $74 \pm 1$ \\
\hline MMS & 2704 & 20.7 & $\mathrm{M}^{4+}$ & $2 \times$ & $10^{6}$ & MMS & 2080 \\
\hline
\end{tabular}

\section{Discussion}

Three of the compounds evaluated showed mutagenic activity with TA104 and TA102 strains. These were captan and folpet with TA104 and captafol with TA102. S9 mix decreased the mutagenic activity of these compounds and the results obtained confirm those obtained by different authors for captan (Ficsor et al., 1977; Shirasu et al., 1977; Carere et al., 1978; de Flora, 1978; Moriya et al., 1978, 1983; Schuphan et al., 1981; Shiau et al., 1981; IARC, 1983; Schuphan and Casida, 1983; de Flora et al., 1984) and for folpet (Shirasu et al., 1977; Moriya et al.,
1978, 1983; Shiau et al., 1981; Schuphan and Casida, 1983) in the Salmonella/mammalian microsome test and for captafol (Shirase et al., 1977; Moriya et al., 1983) in the test carried out with Escherichia coli. The remaining compounds-dichlofluanid, tetrahydrophthalimide and thiazolidine-4-carboxylic acid-were non-mutagenic with these strains.

In all the assays performed with a mutagenic compound, there was a dose-related increase in the number of mutant colonies. However, there were differences from one assay to another. Many factors can have an influence on these differences (Grafe et al., 1981; Friederich and Würgler, 1983; Anderson et al. 1984). In this case, the main factors seem to be the spontaneous reversion and the number of bacteria plated. 
Table XVI. Mutagenic evaluation of tetrahydrophthalimide with TA102

(a) Without 59 mix

Assay $\mathrm{I}^{\mathrm{a}}$

Tetrahydro- $R$

phthalinide

$(\mu \mathrm{g} /$ plate $)$

\begin{tabular}{|c|c|c|c|c|c|c|c|c|c|c|c|c|c|c|c|c|}
\hline Assay $1^{a}$ & & & & & & Asssay II $^{a}$ & & & & & Assay $I I^{3}$ & 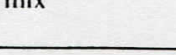 & & & & \\
\hline $\begin{array}{l}\text { Tetrahydro- } \\
\text { phthalimide } \\
\text { ( } \mu \text { g/plate) }\end{array}$ & $\mathrm{R}$ & MI & Q & V & & $\begin{array}{l}\text { Tetrahydro- } \\
\text { phthalimide } \\
\text { ( } \mu \mathrm{g} / \text { plate) }\end{array}$ & $\mathbf{R}$ & MI & $Q$ & V & $\begin{array}{l}\text { Tetrahydro- } \\
\text { phthalinide } \\
\text { ( } \mu \mathrm{g} / \text { plate) }\end{array}$ & $\mathbf{R}$ & MI & Q & V & \\
\hline 80 & $247 \pm 25.46$ & 0.7 & NM1 & & $10^{7}$ & 80 & $101 \pm 36.02$ & 0.3 & NM & $10^{7}$ & 80 & $73 \pm 22.54$ & 0 & NM & $2 \times$ & $\times 10^{4}$ \\
\hline 160 & $269 \pm 51.78$ & 0.8 & NM & & $10^{7}$ & 160 & $129 \pm 33.17$ & 0.7 & NM & $10^{7}$ & $\left.160^{\prime}\right)$ & $67 \pm 7.55$ & 0 & NM & $2 x$ & $\times 10^{4}$ \\
\hline 320 & $285 \pm 58.69$ & 1 & NM & & $10^{7}$ & 320 & $118 \pm 8.72$ & 0.5 & NM & $10^{7}$ & 320 & $75 \pm 13.58$ & 0 & NM & $2 x$ & $\times 10^{4}$ \\
\hline $5(x)$ & $300 \pm 7.07$ & 1.1 & NM & & $<10^{7}$ & 500 & $100 \pm 12.02$ & 0.3 & NM & $10^{7}$ & 500 & $86 \pm 7.78$ & 0 & NM & & $10^{9}$ \\
\hline SM & $122 \pm 6.36$ & & & & $10^{7}$ & SM & $80 \pm 19.52$ & & & $10^{7}$ & SM & $151 \pm 23.43$ & & & & $\times 10^{4}$ \\
\hline DMSO & $164 \pm 8.46$ & 1.3 & NM & & $10^{7}$ & DMSO & $74 \pm 18.45$ & 0.9 & NM & $10^{7}$ & DMSO & $147 \pm 26.50$ & 1 & NM & & $\times 10^{4}$ \\
\hline MMS & 2704 & 20.7 & $\mathrm{M}^{4+}$ & $2 x$ & $\times 10^{h}$ & MMS & 2080 & 25 & $\mathrm{M}^{4+} / \mathrm{T}$ & $<10^{6}$ & 2-AA & 473 & 2.1 & $\mathrm{MN}$ & $3>$ & $\times 10^{k}$ \\
\hline
\end{tabular}

Legend as Table III.

MMS = mutation in response to methyl methane sulphonate.

Table XVII. Mutagenic evaluation of thiazolidine-4-carboxylic acid with TA102

\begin{tabular}{|c|c|c|c|c|c|c|c|c|c|c|c|c|c|c|c|c|}
\hline \multicolumn{7}{|c|}{$\begin{array}{l}\text { (a) Without } 59 \text { mix } \\
\text { Assay } I^{3}\end{array}$} & \multicolumn{5}{|l|}{ Assay $\mathrm{Il}^{\mathrm{J}}$} & \multicolumn{5}{|l|}{$\begin{array}{l}\text { (b) With } S 9 \text { mix } \\
\text { Assay } 11^{3}\end{array}$} \\
\hline $\begin{array}{l}\text { Thiazolidine-4- } \\
\text { carboxylic } \\
\text { acid ( } \mu \mathrm{g} / \text { plate })\end{array}$ & $\mathrm{R}$ & & MI & Q & V & & $\begin{array}{l}\text { Thiazolidine-4- } \\
\text { carboxylic } \\
\text { acid ( } \mu g / \text { plate) }\end{array}$ & $\mathrm{R}$ & MI & Q & V & $\begin{array}{l}\text { Thiazolidine }-4 \text { - } \\
\text { carboxylic } \\
\text { acid ( } \mu \mathrm{g} / \text { plate) }\end{array}$ & R & MI & Q & V \\
\hline 80 & 263 & \pm 39.60 & 0.8 & NM & & $10^{7}$ & 80 & $99 \pm 5.57$ & 0.3 & NM & $10^{7}$ & 80 & $101 \pm 26.03$ & 0 & NM 2 & $2 \times 10^{4}$ \\
\hline 160 & 359 & \pm 111.04 & 1.6 & NM & & $10^{7}$ & 160 & $131 \pm 17.01$ & 0.7 & NM & $10^{7}$ & 160 & $109 \pm 4.62$ & 0 & NM 2 & $2 \times 10^{9}$ \\
\hline 320 & 340 & $\pm \quad 66.47$ & 1.4 & NM & & $10^{7}$ & 320 & $163 \pm 36.55$ & 1.1 & NM & $10^{7}$ & 320 & $101 \pm 19.73$ & 0 & NM 2 & $2 \times 10^{4}$ \\
\hline 500 & 292 & \pm 106.29 & 1 & NM & & $10^{7}$ & 500 & $155 \pm 7.07$ & 1 & NM & $10^{7}$ & 500 & $87 \pm 20.53$ & 0 & NM 2 & $2 \times 10^{4}$ \\
\hline SM & 122 & \pm 6.36 & & & & $10^{7}$ & $\mathrm{SM}$ & $80 \pm 19.52$ & & & $10^{7}$ & SM & $151 \pm 23.43$ & & & $2 \times 10^{9}$ \\
\hline DMSO & 164 & \pm 8.48 & 1.3 & NM & & $10^{7}$ & DMSO & $74 \pm 18.45$ & 0.9 & NM & $10^{7}$ & DMSO & $147 \pm 26.50$ & 1 & NM 2 & $2 \times 10^{9}$ \\
\hline MMS & 2704 & & 20.7 & $\mathrm{M}^{4+}$ & $2 \times$ & $10^{6}$ & MMS & 2080 & 25 & $\mathrm{M}^{4+} / \mathrm{T}$ & $<10^{h}$ & $2-A A$ & 473 & 2.1 & NM 3 & $3 \times 10^{x}$ \\
\hline
\end{tabular}

Legend as Table III.

$\mathrm{MMS}=$ mutation in response to methyl methane sulphonate.

TA102 and TA104 strains do not reach the stationary phase after a 14-h incubation period (Barrueco, 1986) and in some cases it was necessary to count revertants after 5 or 6 days, instead of 2 days, to observe the mutagenic effect, indicating that these strains grow slowly in a liquid as well as in a solid medium.

We used cultures from $14 \mathrm{~h}$ for both strains and in spite of the culture conditions being the same, the bacteria titre changed in different assays for TA104 $\left(10^{7}-2 \times 10^{9}\right.$ viables $\left./ \mathrm{ml}\right)$ and remained constant for TA $102\left(10^{7}\right.$ viables $\left./ \mathrm{ml}\right)$.

The number of spontaneous revertants is dependent on the histidine concentration (Green, 1981; Salmeen and Durison, 1981; Aeschbacher et al., 1983; Anderson et al., 1984); however, in this study, although the concentration was always the same, spontaneous reversion varied from one assay to another. This variation may also be influenced by the copy number of plasmids in individual cell populations (Levin et al., 1982; Maron and Ames, 1983).

As regards strain TA 104, the higher the spontaneous reversion, the higher the captan- and folpet-induced reversion; when spontaneous reversion was similar, the higher the number of bacteria plated, the higher the captan- and folpet-induced reversion. On the other hand, with TA 102 strain, the lower the spontaneous reversion, the higher the captafol-induced reversion.

In order to quantify the mutagenic effect caused by test chemicals we used mutation index and mutagenic potency. The maximum mutation index was 12 for captafol, 7.3 for captan

(b) With $S 9$ mix

Assay II $^{3}$

\begin{tabular}{|c|c|c|c|c|c|c|c|c|c|}
\hline \multicolumn{5}{|l|}{ Assiay $\mathrm{II}^{\mathrm{a}}$} & \multicolumn{5}{|c|}{ Assay ${ }^{1 I^{3}}$} \\
\hline $\begin{array}{l}\text { Tetrahydro- } \\
\text { phthalimide } \\
\text { ( } \mu \mathrm{g} / \text { plate) }\end{array}$ & $\mathbf{R}$ & MI & $Q$ & V & $\begin{array}{l}\text { Tetrahydro- } \\
\text { phthalinide } \\
\text { ( } \mu \mathrm{g} / \text { plate) }\end{array}$ & $\mathbf{R}$ & MI & Q & V \\
\hline 80 & $101 \pm 36.02$ & 0.3 & NM & $10^{7}$ & 80 & $73 \pm 22.54$ & 0 & NM & $2 \times 10^{4}$ \\
\hline 160 & $129 \pm 33.17$ & 0.7 & NM & $10^{7}$ & $\left.166^{\prime}\right)$ & $67 \pm 7.55$ & 0 & NM & $2 \times 10^{4}$ \\
\hline 320 & $118 \pm 8.72$ & 0.5 & NM & $10^{7}$ & 320 & $75 \pm 13.58$ & 0 & NM & $2 \times 10^{4}$ \\
\hline 500 & $100 \pm 12.02$ & 0.3 & NM & $10^{7}$ & 500 & $86 \pm 7.78$ & 0 & NM & $10^{4}$ \\
\hline SM & $80 \pm 19.52$ & & & $10^{7}$ & SM & $151 \pm 23.43$ & & & $2 \times 10^{4}$ \\
\hline DMSO & $74 \pm 18.45$ & 0.9 & NM & $10^{7}$ & DMSO & $147 \pm 26.50$ & 1 & NM & $2 \times 10^{4}$ \\
\hline MMS & 2080 & 25 & $\mathrm{M}^{4+} / \mathrm{T}$ & $<10^{6}$ & 2-AA & 473 & 2.1 & $\mathrm{MN}$ & $3 \times 10^{k}$ \\
\hline
\end{tabular}

phthalinide

phthalinide
$(\mu \mathrm{g} /$ plate $)$ . 
Captan is, however, more toxic than folpet, indicating that the rest of the molecule, i.e. tetrahydrophthalimide or phthalimide, influences the activity of trichloromethylthio moiety.

Captafol showed only a very weak mutagenic effect and this was not always observed with TA100 (Kawachi et al., 1980; Moriya et al.. 1983). This effect was not confirmed in our laboratory (Barrueco, 1986). By using TA102 strain the mutagenicity of captafol was clearly shown. Captafol was nonmutagenic with TA 104. If the structures of captan and captafol are compared, their cyclic groups are scen to be identical, i.e. tctrahydrophthalimide, and the compounds differ in the reactive moiety, which is trichloromethylthio for captan and tetrachloroethylthio for captafol. Both compounds were mutagenic, so both reactive groups seem to be responsible for the attack on the DNA, although their mechanism of action seems to be different. Captafol was the most toxic compound of all those evaluated, and it therefore seems probable that captafol causes more serious damage to DNA than captan or folpet by acting as a crosslinking agent. Thus, the presence of an intact excision repair system in TA102 decreases the toxicity of captafol, allowing the detection of its mutagenic effect.

Dichlofluanid showed only a vėry weak mutagenic effect which was not always observed with TA100 (Shirasu et al., 1977; Schupan et al., 1981; Moriya et al., 1983; Schuphan and Casida, 1983). This effect was not confirmed in our laboratory (Barrueco, 1986) and there was no mutagenic response with either TA102 or TA104 strains. Dichlofluanid has a reactive group similar to that of captan and folpet in which a chlorine has been substituted by a fluorine. Schuphan et al. (1981) found that dichlofluanid and two of its metabolites-thiazolidine-2-thione-4-carboxylic acid and bis-(fluorodichloromethyl)disulfide-were non-mutagenic to TA 100. However, the chlorinated derivative of dichlofluanid was mutagenic to TA100 (Schuphan and Casida, 1983). Everything, therefore, seems to point to the fluorine atom as the cause of the absence of mutagenicity of dichlofluanid. In addition, dichlofluanid was the second most toxic compound after captafol and it is again the fluorine atom which appears as the cause of this toxicity which would prevent the detection of any possible mutagenic effect.

This study has shown that it is necessary to include strains TA 104 and TA102 together with those strains initially used in the Ames test in order to increase the confidence of detecting mutagens and shedding light on their mechanism of action.

The mutagenicity of these compounds has also been evaluated in different derivatives of Escherichia coli WP2 (Bridges, 1975). These strains carry an ochre mutation at a trp locus and can revert by structural gene mutations that include transitions at an A-T base pair or by the formation of ochre suppressors that include transitions at a G-C base pair. It was found that both types of mutation were induced in these strains although with differing proportions and it was necessary to perform another assay with T4 ochre mutant phage in order to establish the mutational specificity of these compounds. However, using a set of Salmonella typhimurium strains we can establish the mutational specificity of these compounds without performing another complementary assay. We thus conclude that Salmonella typhimurium strains are preferable to Escherichia coli strains for the detection of chemicals in this class.

\section{Acknowledgements}

The authors thank Mr L.Cuadra for critical reading on the manuscript. Drs E.Valcarce. C.Canga and A.Herrera for the valuable comments, and P.Gutierrez. M.V.Castano. A.Martincz and F.Sancho for help with the preparation of the manuscript. Special thanks are due to Professor Dr E.Laborda for his advice and to Professor Dr A.Bello for his interest on the publication of this manuscript. This work was funded in part by an FISSS Grant and a grant from the CICyT/CSIC Toxicology Programme.

\section{References}

Aeschbacher.H.U., Friederich.U. and Seiler.J.P. (1983) Criteria for the standardization of Salmonella mutagenicity tests: results of a collaborative study III. The influence of the composition and preparation of the minimal medium in the Salmonella mutagenicity test. Teratogenesis, Carcinogenesis, Mutagenesis. 3, $195-203$.

Ames,B.N., Duston,W.. Yamasaki,E. and Lec,F. (1973) Carcinogens are mutagens: a simple test system combining liver homogenates for activation and bacteria for detection. Proc. Natl. Acad. Sci. USA, 70, 2281-2285.

Ames,B.N., McCann,J. and Yamasaki,E. (1975) Methods for detecting carcinogens and mutagens with the Salmonella/mammalian-microsome mutagenicity test. Mutat. Res., 31, 347-354.

Anderson,D.. Green,M.H.L., Mattern,I.E. and Godley,M.J. (1984) An international collaborative study of 'genetic drift' in Salmonella typhimurium strains used in the Ames test. Mutat. Res., 130, 1-10.

Barrueco,C. (1986) Estudio muagénico del captan y compuestos relacionados mediante el ensayo bacteriano con mutantes de Salmonella typhimurium. Tesis doctoral, Facultad de Ciencias Biológicas, Universidad Complutense de Madrid. 542 pp.

Bridges,B.A. (1975) The mutagenicity of captan and related fungicides. Mutat. Res., 32, 3-34.

Bridges,B.A., et al. (1972) Repair-deficient bacterial strains suitable for mutagenicity screening: test with the fungicide captan. Chem.-Biol. Interactions. 5. $77-84$

Carere,A., Ortali, V.A., Cardamone,G., Torracca,A.M. and Raschetti,R. (1978) Microbiological mutagenicity studies in pesticides in vitro. Mutat. Res., 57. $277-286$.

Ficsor,G., Bordas,S., Wade,S.M., Muthiani,E., Wentz,G.F. and Zimmer,D.M. (1977) Mammalian host- and fluid-mediated mutagenicity assays of captan and streptozotocin in Salmonella typhimurium. Mutat. Res., 48, 1-16.

Ficsor,G., Bordas,S. and Steward,S.J. (1978) Mutagenicity testing of benomyl. methyl-2-benzimidazole carbamate, streptozotocin and $N$-methyl- $N^{\prime \prime}$-nitro- $N$ nitrosoguanidine in Salmonella typhimurium in vitro and in rodent host-mediated assays. Mutat. Res., 51, $151-164$.

de Flora,S. (1978) Metabolic deactivation of mutagens in the Salmonellamicrosome test. Nature. 271, 455-456.

de Flora,S. and Boido, V. (1980) Effect of human gastric juice on the mutagenicity of chemicals. Mutat. Res., 77, 307-315.

de Flora,S., Zanacchi,P., Camoirano,A., Bennicelli,C. and Badolati,G.S. (1984) Genotoxic activity and potency of 135 compounds in the Ames reversion test and in a bacterial DNA-repair test. Mutat. Res., 133, 161-198.

Friederich,U. and Würgler,F.E. (1983) The Salmonella/mammalian-microsome assay: variations of the test protocol: results of a questionnaire returned by 87 laboratories. Teratogenesis, Carcinogenesis, Mutagenesis, 3, 177-182.

Grafe,A., Mattern,I.E. and Green,M. (1981) A European collaborative study of the Ames assay. I. Results and general interpretation. Mutat. Res., 85. 391-410.

Green,M.H.L. (1981) The effect of spontaneous mutation on the sensitivity of the Ames test. Prog. Mutat. Res.. 2, 159-166.

Hollstein,M. and McCann.J. (1979) Short-term tests for carcinogens and mutagens. Mutat. Res., 65, 133-226.

LARC (1983) Captan. In IARC Monographs on the Evaluation of the Carcinogenic Risk of Chemicals to Humans. IARC, Lyon, no. 30, pp. 295-318.

Kawachi,T. et al. (1980) Cooperative programme on short-term assays for carcinogenicity in Japan. In Montesano, R.. Bartsch, H. and Tomatis, L. (eds). Molecular and Cellular Aspects of Carcinogen Screening Tests. IARC Scientific Publications no. 27, pp. 323-330. IARC. Lyon.

Levin,D.E. (1982) A new Salmonella tester stain (TA 102) with A.T base pairs at the site of mutation detects oxidative mutagens. Proc. Natl. Acad. Sci. USA. 79, 7445-7449.

Maron.D.M. and Ames.B.N. (1983) Revised methods of Salmonella mutagenicity test. Mutat. Res.. 113. 173-215.

Mattern,I.E. (1981) Basis of evaluation of an Ames test. Prog. Mutat. Res.. 2. $187-190$.

McCann.J. and Ames.B.N. (1975) Detection of carcinogens as mutagens in the Salmonella/microsome test: assay of 300 chemicals. Proc. Natl. Acad. Sci. USA., 72. 5135-5139.

M(x)re.D. and Felton.J.S. (1983) A microcomputer program for analyzing Ames test data. Mutat. Res.. 119. 95-102.

Moriya.M.. Kato.K. and Shirasu.Y. (1978) Effects of cysteine and a liver 
metabolic activation system on the activities of mutagenic pesticides. Mutat. Res., 57, 259-263.

Mnriya.M.. Ohta.T.. Watanabe.K., Miyazawa.T., Kato,K. and Shirasu,Y. (1983) Further mutagenicity studies on pesticides in bacterial reversion assay system. Mutat. Res., 116. 185-216

Rinkus.S.J. and Legator.M.S. (1979) Chemical characterization of 465 known or suspected carcinogens and their correlation with mutagenic activity in the Salmonella typhimurium system. Cancer Res.. 39, 3289-3318.

Salmeen,I. and Durisin.A.M. (1981) Some effects of bacteria population on quantitation of Ames Salmonella-histidine reversion mutagenesis ascays. Mutat. Res. . 85, $109-118$.

Schuphan,I. and Casida,J.E (1983) Metabolism and degradation of pesticides and xenobiotics: bioactivations involving sulfur-containing substitucnts. In Miyamoto,J. and Kearney,P.C. (eds), Pesticide Chemistry: Human Welfare and the Environment. Pergamon Press, Oxford, Vol. 3, pp. 287-294.

Schuphan,1. et al. (1981) Biological and chemical behavior of perhalogennethylmercapto fungicides: metabolism and in vitro reactions of dichlofluanid in comparison with captan. Am. Chem. Soc. Symp. Ser., 158, 85-96.

Shiau,S.Y., Huff.R.A. and Felkner,I.C. (1981) Pesticide mutagenicity in Bacillus subtilis and Salmonella typhimurium detectors. J. Agric. Food Chem., 29. 268-2خ1.

Shirasu,Y., Moriya,M.. Kato.K., Lienard.F.. Tezuka.H.. Teramoto.S. and Kada.S. (1977) Mutagenicity screening on pesticides and modification products: A basis of carcinogenicity evaluation. In Hiatt,H.H., Watson.J.D. and Winsten,J.A. (eds), Origins of Human Cancer. Book A. Incidence of Cancer in Humans. Cold Spring Harbor Cell Proliferation Series, Vol. 4, Cold Spring Harbor, NY, 267-285.

Sokal,R.R. and Rohlf,F.J. (19880) Introducción a la Bioestadistica. Série de Biología Fundamental. Ed. Reverté, Barcelona.

Waleh,N.S., Rapport.S.J. and Mortelmans,K. (1982) Development of a toxicity test to be coupled to the Ames Salmonella assay and the method of construction of the required strains. Mutat. Res., 97, 247-256.

Waters,M.D. et al. (1982) Study of pesticide genotoxicity. In Fleck,R.A. and Hollaender, A. (eds), Genetic Toxicology. Plenum, New York, pp. 275-326.

Xu,J., Whong,W.-Z. and Ong.T.-M. (1984) Validation of the Salmonella (SV50)/arabinose-resistant forward mutation assay system with 26 compounds. Mutat. Res., 130, 79-86.

Received on November, 2, 1987; accepted on June 1, 1988 